\title{
The Concept of Locus Standi in Collective Protection of Consumer Rights - THE Pitfalls of Transposition of European Model into the Czech Legal Order ${ }^{1}$
}

\section{Klára Hamuláková}

Faculty of Law, Palacký University Olomouc, Czech Republic

\section{klara.hamulakova@upol.cz}

HAMULÁKOVÁ, Klára. The Concept of Locus Standi in Collective Protection of Consumer Rights - the Pitfalls of Transposition of European Model into the Czech Legal Order. International and Comparative Law Review, 2019, vol. 19, no. 2, pp. 200-223. DOI: 10.2478/iclr-2019-0021.

\begin{abstract}
Summary: The paper deals with collective protection of consumer rights from the European and Czech point of view. The attention is focused on the question of the concept of legal standing to bring a collective actions (i.e. locus standi) The article compares the legal regulation of legal standing to bring a collective action in the Commission Recommendation of 11 June 2013 on common principles for injunctive and compensatory collective redress mechanisms in the Member States concerning violations of rights granted under Union law (2013/396/EU), in the proposal a new Directive of the European Parliament and of the Council on representative actions for the protection of the collective interests of consumers [COM/2018/184 final-2018/0089 (COD)] and the Czech bill for the Collective Redress Act.
\end{abstract}

Keywords: protection of consumer rights, collective redress, legal standing to bring a collective action.

\section{Anchoring of procedural protection of consumer rights in the EU and the Czech Republic}

Protection of consumer rights is one of the fundamental policies of the European Union. Emphasis is placed on both public and private forms of protection. However, the legislative activity of the European Union has not significantly affected the regulation of consumer dispute resolution in court proceedings yet ${ }^{2}$ and it leaves this issue more or less in the competence of the individual Member States. Nevertheless, the European Union has been exerting pressure on

1 This article was created with the support of the Czech Science Foundation (GA19-20054S Procedural Specifics of Consumer Dispute Resolution). The article was elaborated as of 2 September 2019.

2 The situation is different in the case of alternative dispute resolution. 
the Member States to ensure that consumer rights are protected at the highest acceptable level. ${ }^{3}$

Collective legal protection has therefore been gaining importance too. The activity of the European Union in this regard has resulted in the adoption of the Commission Recommendation of 11 June 2013 on common principles for injunctive and compensatory collective redress mechanisms in the Member States concerning violations of rights granted under Union law (2013/396/EU; hereinafter referred to as the Recommendation). The Recommendation itself states that amongst those areas where the supplementary private enforcement of rights granted under Union law in the form of collective redress is of value, are consumer protection. At the same time, however, it adds that the principles set out in this Recommendation should be applied horizontally and equally in those areas but also in any other areas where collective claims for injunctions or damages in respect of violations of the rights granted under Union law would be relevant (Article 7 Preamble to the Recommendation). The aim of this Recommendation is to facilitate access to justice in relation to violations of rights under Union law and to that end to recommend that all Member States should have collective redress systems at a national level that follow the same basic principles throughout the Union, taking into account the legal traditions of the Member States and safeguarding against abuse (Article 10 Preamble to the Recommendation).

Directive 2009/22/EC of the European Parliament and of the Council of 23 April 2009 on injunctions for the protection of consumers' interests preceded the Recommendation in consumer matters. The proposal a new Directive of the European Parliament and of the Council on representative actions for the protection of the collective interests of consumers [COM/2018/184 final-2018/0089 (COD); hereinafter referred to as the proposal for a Directive or the Directive $]^{4}$ submitted in April 2018, which has currently passed the first reading and there have been ongoing negotiations concerning its final form, should bring revision of the existing system. The proposed directive is a part of the package New Deal for Consumers submitted by the Commission with the aim to ensure stronger consumer protection in the European Union. ${ }^{5}$ Both the extension of the scope

3 As M. Hulmák pointed out in his Article "Ochrana spotřebitele v rozkazním rrízení", the CJEU in its case-law related to the Directive 93/13/EEC as of 5 April 1993 on unfair terms in consumer contracts developed the requirement of equivalent and effective consumer protection in procedural legislation (cf. Article 7, Subsection 1 of Directive 93/13 / EEC) and a number of CJEU decisions have recently been concerned not with substantive law issues but with the fulfilment of these principles at individual stages and types of court proceedings. HULMÁK, Milan. Ochrana spotřebitele v rozkazním rrízení. Právní rozhledy, $15-16,2019$, p. 515 et seq.

4 This Directive is intended to replace the existing Directive on injunctions for the protection of consumers' interests.

5 This builds on the results of the review of the effectiveness of instruments for protection of consumer rights. Cf. a report of the Commission on the Fitness Check of EU consumer and marketing law and a report on the implementation of the Commission Recommendation. 
of the Directive and the possibility to claim damages in these proceedings are fundamental changes brought by the proposal.

In the Czech Republic, comprehensive legislation on collective rights protection is still missing. In the area of consumer protection, however, reference should be made to the regulation related to legal standing to bring an action contained in Section (\$) 25 of the Consumer Protection Act No. 634/1992 Coll., which is a transposition of the aforementioned Directive 2009/22/EC of the European Parliament and of the Council. According to this Act, a motion to begin court proceedings for injunctions matters concerning protection of consumer rights may be filed by an association or professional organisation which has a legitimate interest in protecting the consumer, ${ }^{6}$ or an entity set out in the list of persons qualified to bring an action for an injunction with respect to the protection of consumer rights, which is maintained by the Commission of the European Communities and published in the Official Journal of the European Union. The Civil Code (act No. 89/2012 Coll.) also allows for initiation of proceedings to refrain from unfair competition or to remedy a defective situation in matters of protection against unfair competition (Sections $\$ 2976, \$ 2988$ of the Civil Code) against persons violating law by unfair competition to a legal entity entitled to defend the interests of competitors or customers (Section $\$ 2989$ Subsection 1 of the Civil Code ). However, proceedings initiated in such a manner do not contain any procedural specifics in comparison with the traditional trial proceedings, with the exception of a specially regulated plea of lis pendens, where the identity of the subject matter and the defendant is sufficient to its origin [Section $\$ 83$, Subsection 2 of the Civil Procedure Code (act No. 99/1963 Coll.)] and res iudicata, The statement in a decision is binding not only for the parties to the proceedings, but also for other persons entitled against the defendant for the same claims resulting from the same conduct or condition (Section $\$ 159 \mathrm{a}$ Subsection 2 of the Civil Procedure Code).

However, such legislation is inadequate, even in the context of the efforts of the EU to achieve more comprehensive regulation and it shows numerous shortcomings. ${ }^{7}$ The Ministry of Justice therefore proceeded to works on the legal regulation of collective judicial protection. In 2017, it published the intended subject-matter of the Collective Redress Act, which was, after the modifications, discussed and approved by the Government in April 2018. In March 2019, the Ministry of Justice submitted the bill for the Collective Redress Act arranged according to section to a circulation of a draft bill for comments and after settling

6 Association pursuant to Section (\$) 214 et seq. of the Civil Code.

7 In relation to this, cf. in detail HAMULÁKOVÁ, Klára, PETROV KŘIVÁČKOVÁ, Jana. Alternative Methods of Collective Disputes Resolution in the Czech Republic. Baltic Journal of European Studies, Tallinn University of Technology (ISSN 2228-0588), Vol. 6, No. 2 (21), pp. 101-102 or PETROV KŘIVÁČKOVÁ, Jana, HAMULÁKOVÁ, Klára. Reprezentativní žaloba v českém civilním procesu. Acta Iuridica Olomucensia, 2016, vol. 11, no. 1, pp. 51-60. 
the comments, it was submitted to the Government (hereinafter referred to as the bill for the Collective Redress Act). ${ }^{8}$

Simultaneously, works on legislation for the collective protection of rights of consumers at both European and national levels are currently underway. At the same time, national legislations in individual EU Member States should be in line with the European one. The principles of collective judicial protection contained in the Recommendation should also be taken into account when establishing or amending the existing mechanisms.

\section{Relationship of the proposal for a Directive and the Recommendation to the national legislation}

According to the proposal for a Directive, the Directive does not replace existing national mechanisms, however, the Directive provides a specific form of representative action thereby ensuring that consumers in all Member States have at least one mechanism with the same procedural modalities at their disposal. Cf. more closely specified point 24 of the recital: This Directive aims at a minimum harmonisation and does not replace existing national collective redress mechanisms. Taking into account their legal traditions, it leaves it to the discretion of the Member States whether to design the representative action set out by this Directive as a part of an existing or future collective redress mechanism or as an alternative to these mechanisms, insofar as the national mechanism complies with the modalities set by this Directive. It does not prevent Member States from maintaining their existing framework, neither does it oblige Member States to amend it. Member States will have the possibility to implement the rules provided for this Directive into their own system of collective redress or to implement them in a separate procedure.

Article 1, Subsection 2 of the Directive on representative actions provides that this Directive shall not prevent Member States from adopting or maintaining in force provisions designed to grant qualified representative entities or any public body other procedural means to bring actions aimed at the protection of the collective interests of consumers at national level. The implementation of this Directive shall under no circumstances constitute grounds for the reduction of consumer protection in fields covered by the scope of Union law. Article 2, Subsection 3a then adds that this Directive is without prejudice to other forms of redress mechanisms provided for in national law.

The proposal for a Directive thus allows for other forms of collective judicial protection, but the minimum standard required by the proposal for a direc-

8 The draft of the intended subject-matter of the Collective Redress Act, including comments on it is available in the Electronic Library of legislation for the public, which is being prepared (VeKLEP).See https://apps.odok.cz/veklep 
tive shall be complied with in order to preserve its purpose. In this respect, the national rules shall not be in conflict with the proposed directive.

Compared to the Directive, the Recommendation does not have a binding character. Its aim is to recommend that all Member States should have collective redress systems at national level that follow the same basic principles throughout the Union, taking into account the legal traditions of the Member States and safeguarding against abuse (Article 10 Preamble to the Recommendation). However, it should undoubtedly have an impact on the final form of the new legislation regulating collective judicial protection in individual Member States.

The efforts stated in these documents and in the bill for the Collective Redress Act are the same. The aim is to strike a balance between the functional protection of consumer rights and provision of sufficient safeguards against the misuse of litigation. ${ }^{9}$ However, the ways to achieve this may vary, the means chosen may be more or less effective and the question then is whether they will hold up side by side.

In the explanatory memorandum to the bill for the Collective Redress Act (Chapter 5, the Assessment of the Compatibility of the Proposed Legislation with the Obligations Arising for the Czech Republic from its EU Membership) it is stated that the submitted bill for the Collective Redress Act is in line with both the Recommendation and the proposal for a Directive regulating representative actions. $^{10}$

The aim of the paper is to evaluate the compliance of these documents. ${ }^{11}$ In view of the scope of the matter, it does so only in relation to the concept of legal standing, which has a fundamental effect on the fulfilment of the above-mentioned efforts. In doing so, it is based on the proposal for a Directive as amended after the first reading within the EU legislative process and the bill for the Col-

9 In relation to this, cf. points 3 and 4 of the recital of the proposal for a Directive and Article 1, Subsection 1 of the proposal for a Directive. Furthermore, cf. points 10 and 15 of the preamble of the Recommendation and Article 1 of the Recommendation. Cf. also Sections $\S 5$ and $\S 6$ of the bill for the Collective Redress Act. Safeguards against abuse have been strengthened in the bill for the Collective Redress Act also in response to numerous comments on the original version of the Bill.

10 Cf. however, the statement contained in the Explanatory Memorandum (p. 78) that national mechanisms may exist in parallel to the Directive ones and not necessarily comply with it.

11 One of the criticisms of the bill for the Collective Redress Act submitted to the circulation of a draft bill for comments was related to the contradiction of the bill for the Collective Redress Act with the proposal for a Directive. Cf., for example ELISHER, David. Hromadné žaloby mezi Českem a Evropou. Právní rádce. https://pravniradce.ihned.cz/ c1-66563880-hromadne-zaloby-mezi-ceskem-a-evropou. In relation to the proposal for a Directive cf. SIMON, Rita. Kolektivní nástroje pro řešení rozsáhlých a systémových problémů - nova forma reprezentativní žaloby? Právní rozhledy, vol. 27, no. 7 (2019), s. 254-258. In relation to bill for the Collective Redress Act then cf. JANOUŠKOVÁ, Anežka. Návrh zákona o hromadných žalobách. Soudce, vol. XXI., no. 1, 2019, pp. 14-22. 
lective Redress Act after incorporation of the comments. Where appropriate, the Article also draws attention to their original wording.

\section{The concept of legal standing to bring a collective action and require- ments for the plaintiff}

There may be traced a dual approach to defining legal standing to initiate proceedings in individual legal regulations of collective redress proceedings. In a broader sense, legal standing is granted both to members of the group and to representative entities, i.e. those entities that are not bearers of the given right in the substantive sphere and they do not even claim it about themselves. ${ }^{12} \mathrm{On}$ the other hand, in the narrower sense, the legal standing is limited only to some of them. In the case of group actions, the legal standing is often dependent on the type of group redress procedure, i.e. whether it is a procedure based on an opt-in or opt-out system. In the case of opt-out proceedings, the legal standing is often limited to the representatives. ${ }^{13}$ On the contrary, in the case of the opt-in system, it is more common that a member of the group directly brings an action. In the case of representative actions, the question of legal standing is clear in this respect. ${ }^{14}$

The representative may then be either an entity approved in advance, a representative approved by the court in an ad hoc manner, or a public authority.

A plaintiff in the collective redress procedure defends the interests of the group and is responsible for conducting the entire proceedings. The loss of group members' autonomy is an inherent and reasonable consequence of the nature of a collective redress procedure. ${ }^{15}$ Of course, the requirements imposed on the plaintiff shall correspond to this. In the context of an action for collective redress, we talk about the so-called adequacy of representation.

In addition to the personality and professional qualities of the plaintiff, the adequacy of representation also includes his/her sufficient financial security. ${ }^{16}$ This is intended not only to prevent bringing unfounded actions, but also to

12 For example, in Sweden, depending on the plaintiff, there are three types of actions. These types are a private group action, which may be brought by a natural or legal entity who is a member of a group, an organisation action and a public group action.

13 For example, in Denmark it is a public authority - Danish Consumer Ombudsman

14 The term representative action is used here in the traditional sense, i.e. for actions, respectively proceedings in which persons whose interests are the subject of the proceedings do not participate in it in any way. A group action brought by a representative entity is sometimes referred to as a representative one. The entities concerned, who, however, have a specific position in the proceedings and take part in the proceedings in various extent.

15 FALLA Elodie. Powers of the judge in collective redress proceedings. Research paper submitted to BEUC, 2012, p. 37.

16 For more details on funding, cf. Article HAMULÁKOVÁ, Klára. Funding of Collective Actions. International and Comparative Law Review, 2016, vol. 16, no. 2, pp. 127-144. DOI: 10.1515/iclr-2016-0019 and the literature contained therein. 
contribute to the smooth running of the proceedings and to ensuring that the defendant is reimbursed for the costs of the proceedings if the plaintiff is unsuccessful. Transparent financing is intended to avoid any possible conflicts of interest for potential third parties providing the financing with group members and the defendant. Depending on the type of plaintiff, additional requirements for the plaintiff may then be set. ${ }^{17}$

Fulfilling the requirement of adequate representation is usually one of the prerequisites for certification ${ }^{18}$ of group litigation and it is required for the period of duration of the proceedings.

The concept of legal standing and the requirements imposed on plaintiffs have a significant impact on the level of application of group actions ${ }^{19}$, while stricter claims are associated with a lower level of possible abuse of group actions, but of course, there is a risk that they will not be fully used. ${ }^{20}$

\section{The legal standing to bring a collective action in the proposal for a Directive}

In the proposal for a Directive, legal standing to bring an action is limited only to pre-determined qualified representative entities (representatives). The Member States ${ }^{21}$ are to designate at least one qualified representative entity.

Member States shall ensure that consumer organisations meeting the criteria listed in Subsection 1 and public bodies are eligible for the status of qualified representative entity (Article 4, Subsection 3 of the proposal for a directive).

The requirements for qualified representative entities are:

1. it is properly constituted according to the law of a Member State;

2. its statutes or another governance document and its continued activity involving the defence and protection of consumers interests demonstrate its legitimate interest in ensuring that provisions of Union law covered by this Directive are complied with

17 In relation to this, Cf. a study Collective Redress in the Member States of the European Union prepared by the Policy Department for Citizens' Rights and Constitutional Affairs, October 2018, p. 29.

18 The bill for the Collective Redress Act uses the term "decision on the admissibility of collective action" and this term will therefore be used in connection with the bill.

19 Cf. HESS, Yulia. Proposed Collective Redress in Europe in the Perspective of Deterrence of Corporate Wrongdoing. European Company Law 10, no. 3 (2013) s. 123-128.

20 Cf. also study Collective Redress in the Member States of the European Union prepared by Policy Deppartment for Citizens' Rights and Constitutional Affairs, October 2018, s. 15.

21 The proposed amendment thereof allowed for this qualified representative entity to be designated by a court of a Member State, but at the same time the possibility of designating an ad hoc qualified representative entity for a specific procedure was deleted. The appointment of a qualified representative body by the court is therefore clearly not practically feasible. 
3. it has a non-profit making character;

4. it acts in a way that is independent from other entities and from persons other than consumers who might have an economic interest in the outcome of the representative actions, in particular from a market operator;

5. it does not have financial agreements with plaintiff law firms beyond a normal service contract;

6. it has established internal procedures to prevent a conflict of interest between itself and its funders.

The scope of the requirements for qualified representative entities was extended by the amendment by the last three mentioned assumptions. Originally, that provision contained only the criteria necessary for the authorization of this entity by the State. However, some of the supplemented requirements do not correspond to this, their fulfilment may be verified only by the court in relation to the specific proceedings taking place.

Another requirement, the fulfilment of which is assessed by the court, is sufficient financial security of a qualified representative entity. The qualified representative entity seeking a redress order shall submit to the court or administrative authority at the earliest stage $e^{22}$ of the action a complete financial overview, listing all sources of funds used for its activity in general and the funds that it uses to support the action. The qualified representative authority shall demonstrate that it has sufficient financial resources to represent the best interests of the consumers concerned and to meet any adverse costs should the action fail (Article 7, Subsection 1 proposal for a directive). Thanks to this disclosure of financial resources, the court is able to assess the fulfilment of another requirement, which is the absence of a conflict of interest, if the proceedings are financed by a third party. ${ }^{23}$ However, the proposal for a Directive seeks transparent financing only in connection with actions for damages. However, in my opinion, there is no reason for such a narrowing concept. The other collective proceedings are also costly, in case of failure, the plaintiff has to reimburse the costs of the proceedings to the defendant and there occurs a risk of a conflict of interest on the part of the third party providing the financing. Without knowledge of the court that the plaintiff has sufficient financial security and the resources, the court is unable to assess whether the plaintiff is able to comply with the above-mentioned requirements.

22 In the context of the certification decision, this issue shall already be assured.

23 Cf. also Article 7, Subsection 2 of the proposal for a Directive, according to which Member States shall ensure that in cases where a representative action for redress is funded by a third party, it is prohibited for the third party: (a) to influence decisions of the qualified entity in the context of a representative action, including on settlements; (b) to provide financing for a collective action against a defendant who is a competitor of the fund provider or against a defendant on whom the fund provider is dependant 
The court shall furthermore investigate in every specific case whether the purpose of the qualified entity justifies its taking action in a specific case (Article 4, Subsection 5 of the proposal for a Directive ${ }^{24}$ ).

The amendment caused narrowing of the legal standing to bring an action only to predetermined qualified representative entities (including public bodies), whereby the possibility to designate a qualified entity ad hoc for a specific representative action was deleted from the previous version. However, this may be a problem, given the fact that the requirement of purposefulness mentioned as the last one, where it is not clear whether it is sufficient that the purpose of a consumer association is to protect consumers' rights or whether this purpose will be required more specifically, following the given procedure. However, the scope of the Directive is relatively broad. Cf. also amended Article 5, Subsection 1 of the proposal for a Directive on representative action $s^{25}$ : Member States shall ensure that representative actions can be brought before national courts or administrative authorities only by qualified representative entities and provided that there is a direct relationship between the main objectives of the entity and the rights granted under Union law that are claimed to have been violated in respect of which the action is brought. If specialization of qualified representative entities was necessary, there could easily arise a situation in which there would be no pre-approved qualified representative entity with legal standing to bring a specific procedure.

\section{Legal standing to bring a collective action in the context of the Reco- mmendation}

The conditions for the representing entity are stipulated in a similar manner by the Recommendation. The representing entity is determined in advance and the public authority should be empowered with the legal standing to bring an action. However, most often, it is an ombudsman. ${ }^{26}$ In contrast with the proposal

24 In its original version, this Article referred only to Article 5, Subsection 1, now there is a reference to Articles 4 and 5, Subsection 1, it is most probably correct to refer to Articles 5 and 6, that is to say, both types of actions, although they are already included in Article 5, Subsection 1.

25 It is related to both actions, although not conceptually covered by Article 5, which consequently only concerns injunctive actions.

26 For example, the Swedish Group Proceedings Act states that the so-called public group action may be instituted by an authority that, taking into consideration the subject of dispute, is suitable to represent the members of the group. The Government decides which authorities are allowed to institute public group actions. The Consumer Ombudsman and Swedish Environmental Protection Agency are the authorities appointed in this manner. Only one action has been filed so far - see District Court of Umeå, November 2011, T 5416-04, The Consumer Ombudsman ./. Stävrullen Finance AB. The Office for the Protection of Competition has also been taken into consideration in Sweden as well. However, this was not realized because the public-law means of protection in this area are not sufficient. Such an action would therefore not contribute to the public interest. See Group 
for a directive, the Recommendation counts on the fact that the entities approved by the court ad hoc will be able to take the role of representatives.

These conditions should include at least the following requirements (Cf. Article 4 of the Recommendation):

- the entity should have a non-profit making character;

- there should be a direct relationship between the main objectives of the entity and the rights granted under Union law that are claimed to have been violated in respect of which the action is brought; ${ }^{27}$ and

- the entity should have sufficient capacity in terms of financial resources, human resources, and legal expertise, to represent multiple claimants acting in their best interest. ${ }^{28}$

As stated in the Report from the Commission to the European Parliament, the Council and the European Economic and Social Committee COM(2018) 40 final on the implementation of the Commission Recommendation of 11 June 2013 on common principles for injunctive and compensatory collective redress mechanisms in the Member States concerning violations of rights granted under Union law (2013/396/EU): Rules on standing to bring representative actions are procedural guarantees that benefit both claimants and defendants in collective actions. Standards ensuring the expertise of representative entities and their capacity to deal with complex cases ensure high-quality services for claimants and also protect defendants against frivolous action. ${ }^{29}$

Even the Recommendation explicitly requires the plaintiff to be obliged at the outset of the procedure to communicate to the court the source of the funds they will use to support their legal action (Article 14 of the Recommendation, cf. also Subparagraph 18 of the preamble to the Recommendation). The purpose is again to ensure the proper conduct of the procedure, to protect the defendant in the event of their success in the dispute and, last but not least, to detect a possible

Proceeding Fact Sheet, Sweden, Ministry of Justice quoted in accordance with PARSONS, Michelle. European Class Actions. South Carolina Journal of International Law and Business, 2008, vol. 35, no. 4, p. 42. Available at HeinOnline. In Denmark, the Danish Consumer Ombudsman is authorized to file an action, while it is the only possible plaintiff in the opt-out regime. In Poland, the District (Municipal) Consumer Ombudsman is authorised to file such an action (in accordance with Article 2, Subsection 2 of the Group Proceedings Act regulating collective redress).

27 In accordance with the Recommendation, it should be a condition even for a representing entity determined in advance, only the court within the framework of a specific proceeding is able to assess the fulfilment of this requirement though.

28 The recommended legal expertise may, however, be bridged by an obligatory legal representation of the plaintiff at the stage of the court proceeding.

29 Report from the Commission to the European Parliament, the Council and the European Economic and Social Committee $\operatorname{COM}(2018) 40$ final on the implementation of the Commission Recommendation of 11 June 2013 on common principles for injunctive and compensatory collective redress mechanisms in the Member States concerning violations of rights granted under Union law (2013/396/EU), p. 4. 
conflict of interest in the case of third party financing of the procedure (cf. Articles 15 and 16 of the Recommendation). Contrary to the proposal for a directive, this obligation of the plaintiff is required both in action for damages and in injunctive actions (Part III. of the Recommendation of the Principles Common to Injunctive and Compensatory Collective Redress).

\section{Legal standing to bring a collective action in the context of the bill for the Collective Redress Act}

\subsection{Entities entitled to legal standing}

The bill for the Collective Redress Act grants the legal standing to a member of a group, person of interest and the so-called group administrator, depending on the type of procedure and the law applied in it.

A member of a group is the one whose right forms the subject of the collective redress procedure together with the rights of other members of the group. If a member of a group initiates a group redress procedure, they become a participant in the procedure, respectively party to the procedure and also the so-called representative of the group [Section ( $\$$ ) 12, Paragraph b) of the bill for the Collective Redress Act].

The collective redress procedure is challenging not only procedurally, but also financially and organizationally (e.g. necessary informing of group members in cooperation with the court, distribution of the amount gained thanks to the procedure). Meeting the requirements of adequate representation and proving their fulfilment may be difficult for a member of the group himself/herself. The bill for the Collective Redress Act is aware of the risks associated with the legal standing of a member of a group and is therefore limited to the opt-in procedure only (Section $\$ 11$ of the bill for the Collective Redress Act). ${ }^{30}$

The person of interest is a legal entity fulfilling the conditions laid down in the bill for the Collective Redress Act and always a legal entity that is included in the list of authorized persons maintained by the European Commission in accordance with the Consumer Protection Act (Section $\$ 15$ of the bill for the Collective Redress Act).

The person of interest is entitled to the opt-in legal standing to bring an action (Section $₫ 17$, Subsection 1 of the bill for the Collective Redress Act). In the case of opt-out collective redress procedures, the legal standing of the person of interest is limited to determining whether there exists a legal relationship or

30 E.g. the Swedish (section 4 Group Proceedings Act, a personal group action) and the Polish legislation (Article 4 of the Group Proceedings Act regulating collective redress) make it possible for a member of a group to bring an action. 
right or not, or to refrain from unlawful conduct (Section $₫ 17$, Subsection 2 of the bill for the Collective Redress Act).

The group administrator should be an entity accredited by the Ministry of Justice. It may also be a person of interest if they meet the statutory requirements.

The group administrator has the widest authorisation for legal standing. They are a predetermined qualified representative entity both within the framework of the proposal for a Direction and the Recommendation. However, it should be noted that the non-profit nature of an entity is not a prerequisite for the approval of a certain entity as a group administrator as required by the Recommendation or the proposal for a Directive.

The administrator of the group is authorized to initiate the opt-in and optout procedure. However, the opt-in action shall be approved by a member or members of a group or association of interest. Written consent of at least one group member, who then gets into the position of the representative of the group [Section $\$ 12$, Subsection 1, Paragraph a) of the bill for the Collective Redress Act ] is required for filing an opt-in action (Section $₫ 13$, Subsection 2 of the bill for the Collective Redress Act). In the case of a collective opt-out procedure, it is necessary for the plaintiff to submit a written consent of the person of interest or at least 50 members of the group [Section $\$ 34$, Subsection 1, Paragraph c) of the bill for the Collective Redress Act].This does not apply if the plaintiff also fulfils the conditions for the activity of the person of interest, i.e. the group administrator is also the person of interest.

The granting of procedural standing to a group administrator is somewhat problematic in terms of procedural aspects. As A. Winterová points out, there are very few cases of procedural standing in the current legal order; in a free society, it is primarily the issue of right-holders to defend and care for their rights (vigilantibus iura), but they cannot be excluded either. ${ }^{31}$ Unlike an interest association, a group administrator has no interest in common with the interests of group members. Their only interest is the property interest, i.e. obtaining a financial remuneration in the event of winning a dispute. The original objective of a group administrator was defined as a private entrepreneur, an investor whose business is to bring claims with a collective element in a collective procedure. The result of the procedure is binding for members of the group. Thus, if, according to the procedural concept of a party to a dispute, it is possible for someone else to act in their own name as a party not involved in a substantive legal relationship, another consequence is that the effects of that activity may have an impact on someone else who is different than this party. For when procedural law serves to protect substantive rights, while the same law does not allow - for various reasons - the person who is the subject of such substantive law to enforce that protection on their

31 WINTEROVÁ, Alena. Civilní právo procesní. Díl první: řízení nalézací. Praha: Leges, 2018, p. 137. 
own and puts it into the hands of another party making it the party to a dispute, it would obstruct the purpose of itself if it had not drawn a single natural consequence from it: that the results of that party's activities directly affected the subject of the substantive law or at least directly involved in the outcome of the dispute, either exclusively or leading their own parties. ${ }^{32}$ Compared to foreign legislation, such a concept of legal standing is at least a non-standard one.

\subsection{Requirements for plaintiff}

The bill for the Collective Redress Act provides that the collective procedure may be conducted if, inter alia, it has been established that the plaintiff adequately defends the interest of the group, ${ }^{33}$ in particular that there is no conflict of interest with them (Section $\$ 32$ of the bill for the Collective Redress Act). ${ }^{34}$ The so-called adequate representation is one of the conditions for certification of the collective procedure. A demonstrative list of the plaintiff's obligations is given in Section ( $\$$ ) 20 of the bill for the Collective Redress Act (cf. also Section $₫ 19$ of the bill for the Collective Redress Act).

Special requirements are then enshrined in the bill for the person of interest and group administrator.

Pursuant to the bill for the Collective Redress Act, a person of interest means a legal entity that: a) was established in accordance with the legislation of the Czech Republic; b) is not established for generating profit; c) is independent; d) protection of rights or legitimate interests in connection with which the collective procedure is to be led is their main aim, e) has been actively engaged in the protection of these rights or interests for two years and has established a website on which they publicly report on their activity and which implies compliance with the foregoing conditions (Section $₫ 15$ of the bill for the Collective Redress Act).

The condition for granting accreditation for the performance of the activity of a group administrator is: a) integrity, b) credibility, c) a transparent ownership structure if the group administrator is a legal person, and d) professional competence (Section $\$ 168$ of the bill for the Collective Redress Act).$^{35}$ The requirement for a non-profit nature is absent in the bill for the Collective Redress Act.

32 HORA, Václav. Učebnice civilního práva procesního. Praha: Spolek čsl. právníků VŠEHRD, 1947, pp. 144-145.

33 However, it is very difficult to determine what the common interest of the group members is. The interests of the plaintiff may often be contrary to the interests of some members of the group. Such a situation can be solved by creating subgroups.

34 The explanatory memorandum to the bill for the Collective Redress Act mentions in this respect: the court addresses the issue of adequate representation not only in relation to the plaintiff, ... but also in relation to their possible legal representative. Cf. p. 166-167. However, this does not follow from the wording of the Act.

35 In relation to individual requirements, cf. in more detail Section (\$) 169 et seq. of the bill for the Collective Redress Act. 
The activity of the group administrator is to file collective actions, exercise the rights and obligations of the plaintiff in a collective procedure and other acts necessarily related thereto, in particular acts aimed at preparing the collective procedure and receiving and executing proposals and suggestions of members of a group (Section $\$ 167$, Subsection 1 of the bill for the Collective Redress Act). Therefore, the group administrator should be an entity that will have sufficient capacity to conduct group litigation, including the opt-out one, not only organizationally, but also financially. The group administrator, as is the case for all plaintiffs, will finance the entire procedure and in the case it is unsuccessful will reimburse the costs of the procedure to the other party.

Therefore, the bill for the Collective Redress Act envisages that the group administrator will have to prove adequate financial security. Unfortunately, the solvency condition is not a condition for the group administrator to be accredited. The demonstration of adequate financial security is required only in the course of the collective procedure. In addition, the explanatory memorandum states that this selected solution is more appropriate and that the mentioned measure will finally allow, for example, non-profit organizations, which would otherwise not be able to fulfil the general solvency condition, to be eligible for the position of a group administrator, nevertheless, they will be able to fulfil this condition in a specific case. ${ }^{36}$ In those circumstances, it is therefore possible to ask why persons of interest should not be entitled to general legal standing if we allow them to be a group administrator, but there is no need to prove sufficient financial security at the accreditation stage.

The bill for the Collective Redress Act requires the fulfilment of this obligation already at the certification stage, at the latest within 30 days from the date of filing the collective action, or within a period to be determined by the court in a resolution by which it rules on a petition for determining an amount derogating from the law (Section $₫ 39$ of the bill for the Collective Redress Act). Originally, the bill for the Collective Redress Act, set the obligation to prove the solvency condition for the group administrator, which should be met within 30 days from the date when the resolution on the admissibility of group actions entered into force, otherwise the court would decide to terminate the procedure (Section $₫ 36$ of the bill for the Collective Redress Act in the version of circulation of a draft bill for comments). The explanatory memorandum justified this regulation by the fact that the question of whether or not the court certifies a group action may be very ambiguous. At the same time, the question of certification is crucial for the plaintiff and allows them to be able to assess the risk of the procedure better. ... Therefore, the plaintiff can prove their solvency only when it is already apparent from the discussion of the terms of the procedure that the court will admit the group action and at the same time the value of the claimed performance upon which the amount

36 The explanatory memorandum to the bill for the Collective Redress Act, p. 174. 
of security is calculated will be set accurately. ${ }^{37}$ However, certification should only take place after all prerequisites are met. The certification phase is very demanding, certification of the procedure has significant impacts, for example, on the running of limitation periods, as the start of the running of the opt-in or optout period is connected with the certification. It is therefore not possible for the court, after reaching its conclusion, to find out that the plaintiff does not meet the solvency condition and is therefore obliged to terminate the procedure. However, the explanatory memorandum to the bill for the Collective Redress Act itself stated that this obligation had to be fulfilled during the first phase of the procedure and the collective procedure could not proceed with discussing the substance of the case without complying with the obligation. Nor can it be accepted that the plaintiff first initiates such an important procedure before seeking funds for the litigation. Especially if the subject is to be accredited in advance and is expected to have a higher degree of care. Following numerous comments from some commentary points and the professional public, the proposed legislation was amended in this point. ${ }^{38}$

The plaintiff's obligation to comply with the solvency condition is linked only to an opt-out collective procedure in which the plaintiff seeks the imposition of an obligation to act, that is to say, this only influences the group administrator of the group of plaintiffs. The explanatory memorandum to the bill for the Collective Redress Act states that in the case of an opt-out collective procedure with an obligation to act (in particular the obligation to pay a monetary contribution) is the greatest risk of abuse and possible heavy burden lies on the defendants in terms of the costs of the procedure they are not able to gain from the plaintiff after the termination of the procedure ${ }^{39}$ However, it is not possible to agree with this claim. The same financial burden may also be found in other types of procedures where the defendant is not protected by law, respectively they are protected by the imposition of an obligation to provide security only upon the decision of the court.

In order to meet this condition, the plaintiff shall prove that they have adequate funds, insurance or collateral to fulfil a possible obligation to pay the costs of the collective procedure, to compensate for damage, to recover undue payments or to fulfil any other obligation arising in connection with their activity in the current collective procedure (Section $\$ 36$ of the bill for the Collective Redress Act). This is also reflected in the ways in which the solvency condition can be met (Section $\$ 37)$. These are: a) deposit of a security for court custody, b) proof of insurance

37 While the amount of the security, the minimum insurance limit or the limit of the bank guarantee is determined on the basis of the value of the amount claimed, the exact value of the amount claimed is not clear at this stage.

38 Cf. ELIÁŠ, Karel. Zpráva o VII. zasedání Kolegia pro občanské právo při Ústavu státu a práva AV ČR, v. v. i., k problematice hromadných žalob. Právník, č. 6, 2019, p. 613 et seq.

39 The explanatory memorandum to the bill for the Collective Redress Act, pp. 173-174. 
in the case this obligation arises, and c) proof of ensuring that this obligation is fulfilled by a bank guarantee.

However, such a solvency condition cannot meet another of the objectives the proving of sufficient financial security should fulfil, namely ensuring the proper conduct of the procedure. The deposit of a security, proof of insurance or proof of the fulfilment of a bank guarantee does not ensure that the group administrator has sufficient financial resources to properly conduct the procedure and thus effectively defend the interests of the members of the group.

The amount of security, minimum insurance limit or bank guarantee is stipulated by law. ${ }^{40}$ The court may, at the request of one of the parties, decide on an amount other than the statutory amount of security, a minimum limit and bank guarantee (Section $\$ 38$ of the bill for the Collective Redress Act), which may be both higher and lower amount. In addition, the explanatory memorandum to the bill for the Collective Redress Act states that procedure may be initiated by a group administrator that is a non-profit organization and may not (and usually will not) have such funds at its disposal. This condition should discourage, among other things, abuse. In the case of the incumbent non-profit entities, however, abuse is already excluded because they are charitable, publicly known entities that do not generate profit and benefit primarily from their reputation. Discrediting them could damage them irreversibly and therefore, it is not necessary to insist on such a high amount in their case.$^{41}$ However, the explanatory memorandum fails to state that the solvency condition is not only a safeguard against the misuse of collective actions but, in particular, the protection of the defendant if the plaintiff is to bear the costs of the procedure.

For the same purpose, the bill for the Collective Redress Act also regulates the institute of security upon the defendant's proposal (Section $\$ 94$ et seq. of the bill for the Collective Redress Act). ${ }^{42}$ Any plaintiff, not just the group administrator, has the obligation to deposit such security upon the defendant's request, since the institute is not limited to the opt-out procedure only. ${ }^{43}$ In the wording of the bill for the Collective Redress Act after the circulation of a draft bill for comments, it is already possible for the court to impose the obligation to deposit a security even if it has already been deposited in connection with the fulfilment of the solvency condition. ${ }^{44}$ The proposal may be submitted and the obligation

40 In relation to the amount of the guarantee, the minimum insurance limit or the bank guarantee, cf. Section $(\$) 38$.

41 The explanatory memorandum to the bill for the Collective Redress Act, p. 176.

42 If there is a concern that the applicant would not, in the event of their failure, reimburse the defendant for the costs of the procedure or damage caused in connection with the breach of an obligation within the framework of the collective redress action, the court may, upon the proposal of the defendant, order the plaintiff by the means of a resolution to provide reasonable security to compensate for it.

43 Even the group administrator shall deposit it in the event of any opt-out procedure.

44 Cf. also the explanatory memorandum to the bill for the Collective Redress Act, p. 227. 
to deposit a security may be imposed both at the certification stage (then it is one of the conditions for certification) and at the stage of the procedure in the matter itself. The termination of the procedure is the consequence of the failure to comply with the obligation to deposit a security. ${ }^{45}$

In addition to demonstrating that the plaintiff has sufficient financial security, it is essential that the financing is sufficiently transparent for the proper conduct of the judicial procedure. From the point of view of possible misuse of a collective action, it is not only important whether the plaintiff has funds (the solvency condition), but also where they have obtained such funds. ${ }^{46}$ However, the original bill for the Collective Redress Act did not require the plaintiff to reveal the financial resources making them transparent for certification of the procedure. The current bill already contains the condition of transparency of financing (Section $\$ 40$ et seq. of the bill for the Collective Redress Act). Again, this condition applies only to the opt-out procedure (unlike the solvency condition, it is no longer restricted to the specific subject-matter of the procedure). Here too, the constriction seems to me to be imprudent.

According to the explicit wording of the bill for the Collective Redress Act (Section $\$ 42$, Subsection 1 of the bill for the Collective Redress Act), the condition of transparency should be taken into account within the framework of the general conditions of certification pursuant to Section $\$ 32$, Paragraph e) and g) of the bill for the Collective Redress Act, i.e. it shall be certified that $e$ ) the plaintiff adequately defends the interest of the group, especially when they are not in a conflict of interest with it (adequate, appropriate representation), $g$ ) the collective action was not filed with abusive intent, in particular with a view to unlawfully cause harm to members of the group, the defendant and/or a person participating in competition. It is therefore a separate condition of a collective opt-out procedure, the results of which the court will take into account when assessing another condition. ${ }^{47}$

45 In addition to this, it is necessary to point out, in connection with the deposited security (both on the basis of a court decision as well as the fulfilment of the statutory condition of proving solvency) that the deposited security is returned when the time limit for exercising the right for satisfaction from the deposited security expires (which is 3 years in the event of harm due to a breach of the obligation in a collective redress procedure) or if the security has not been used to reimburse the costs or damage caused by a collective procedure for another reason, which is a relatively long time.

46 The explanatory memorandum to the bill for the Collective Redress Act, p. 177.

47 It should be pointed out, however, that Section ( $\$$ ) 22 of the bill for the Collective Redress Act, on the other hand, conveys a condition of transparency separate from the other conditions of certification when referring to the fact that the court dismisses the plaintiff a) if the plaintiff no longer meets the conditions following from this Act, e) it becomes apparent that, when complying with the condition of transparency of funding, the plaintiff has stated apparently incorrect information on the means of financing their activity in the collective redress procedure, misrepresented the data or deliberately withheld part of the data or other material facts. While the ground for dismissal was based on the reason that 
The plaintiff shall prove to the court the funds from which they will finance their activities in the collective opt-out procedure in the first act they made in the collective redress procedure (Section $\$ 40$, Subsection 1 of the bill for the Collective Redress Act) ${ }^{48}$ At the same time, it may not necessarily be required to comply with that obligation at the time the action is brought. If this is to be a condition of certification, the plaintiff should prove it by this point.

The court shall in particular take into account: whether the financing entity, trust fund or other similar legal arrangement without legal personality is not in conflict of interest with the interest of the defendant or with the interest of the group (Section $₫ 42$, Subsection 2 of the bill for the Collective Redress Act).

\section{Consistency of the proposed regulations}

\subsection{Type range of entities entitled to legal standing to bring an action}

The scope of entities entitled to bring an action is wider in the bill for the Collective Redress Act than in the proposal for a Directive. In addition to a predetermined entity, which is the group administrator in the proposed Czech legislation, a member of the group and a person of interes $\mathrm{t}^{49}$ is ad hoc entitled to legal standing. The group of entities thus established is essentially identical with the group of plaintiffs defined in the Recommendation, while the Recommendation envisages, in addition to a predetermined representative entity, the possibility of bringing an action by a representative entity ad hoc approved by a court. Although the Recommendation does not explicitly provide for the possibility of bringing an action by members of a group, it does not in principle preclude this. From article 17 and 18 of the preamble of the Recommendation, it may be induced that it more or less counts with this fact, as it states that legal standing to bring a collective action in the Member States depends on the type of collective redress mechanism. In certain types of collective actions, such as group actions where the action can be brought jointly by those who claim to have suffered harm, the issue of standing is more straightforward than in the context of representative actions, where accordingly the issue of legal standing should be clarified. In the

the applicant no longer fulfilled the conditions certainly includes even such cases where it is subsequently found out that the plaintiff had never fulfilled those conditions.

48 The explanatory memorandum explains in relation to the concept of the first act explains that this obligation applies both for the plaintiff who initiated the procedure and for each of their successors. Consequently, its fulfilment does not relate directly to bringing an action, but in general to any act which the claimant performed in a collective procedure as the first one (typically, but not necessarily an action). However, it must be said that the legal successor of the plaintiff is subject to all the certification conditions connected with the plaintiff. Without their fulfilment, it is not possible for the court to admit a new plaintiff to enter the procedure or to replace the plaintiff (cf. Section $\$ 25$, Subsection 2 and 3 and Section $\$ 27$ of bill for the Collective Redress Act).

49 This in fact corresponds to the qualified representative body in accordance with the proposal for a Directive. 
case of a representative action, the legal standing to bring the representative action should be limited to ad hoc certified entities, designated representative entities that fulfil certain criteria set by law or to public authorities.

Article 5, Subsection 1 of the proposal for a Directive expressly states that member States shall ensure that representative actions can be brought before national courts or administrative authorities only by qualified representative entities designated in accordance with Article 4, Subsection1. Extending legal standing to bring the collective action even by ad hoc representing entities and members of the group may, however, prevent collective actions from not being used in certain types of disputes. The Council of Bars and Law Societies of Europe (CCBE) also criticizes the limitation of legal standing to qualified representative entities only. In the situation when a representative action is not filed by any qualified entity, citizens who meet the criteria for joining a group procedure have no legal means of exercising their rights collectively, even if it is them who have suffered harm..$^{50}$

In contrast, the bill for the Collective Redress Act does not provide for legal standing to initiate the procedure of a public authority. The proposal for a Directive systematically classifies it as a predefined qualified representative entity (cf. Article 4, Subsection 3 of the proposal for a Directive: Member States shall ensure that, in particular, consumer organizations meeting the criteria referred to in Subsection 1 and public bodies are eligible for qualified representative entity status). The Recommendation presents it alongside predetermined entities and entities approved ad hoc (cf. Article 7 of the Recommendation: In addition, or as an alternative, the Member States should empower public authorities to bring representative actions).

\subsection{Requirements for predetermined qualified representative entities}

In accordance with Article 4, Subsection 3 of the proposal for a Directive, Member States shall ensure that consumer organisations meeting the criteria listed in Subsection 1 and public bodies are eligible for the status of a qualified representative entity. However, the proposed Czech legislation does not correspond with this objective. Consumer organisations are more or less considered rather as ad hoc representatives with a limited legal standing to bring a collective redress procedure. In the position of a qualified predetermined representative entity, i.e. according to the proposed Czech legislation in the position of the so-

50 The opinion is based on the fact that only a qualified representative entity in the form of a consumer organization is entitled to legal standing to bring a collective redress procedure. For details cf. the CCBE position on the Proposal for a Directive on representative actions for the protection of the collective interests of consumers. https://www.ccbe.eu/ fileadmin/speciality_distribution/public/documents/ACCESS_TO_JUSTICE/ATJ_Position_papers/EN_ATJ_20180924_CCBE-position-on-the-Proposal-for-a-Directive-onrepresentative-actions-for-the-protection-of-the-collective-interests-of-consumers-andrepealing-Directive-200922EC.pdf 
called group administrator, persons of interest may be accredited as well, but they certainly will not actually form the prevailing group of group administrators. The proposed legislation does not provide them with such a status. This is indicated by the requirements for this qualified representative entity, which lacks the requirement of non-profitability of such an entity and the direct link between the main objectives of the entity and the rights about which it is claimed in the action that they had been infringed. On the other hand, only the property interest will often be the sole interest of the group administrator. ${ }^{51}$

There may arise a problem in the context of the mutual recognition of predetermined representative entities. Not all group administrators will be mutually recognized. Member States shall draw up a list of representative entities, which they shall submit to the Commission and publish that list. Only entities meeting the given criteria could be on this list.

On the other hand, it is obvious that even the absolute insistence on consumer organizations as the only possible plaintiffs may not be ideal. In fact, they are not always sufficiently active in litigation, not only because of their high professional demands, but also because of the financial ones. ${ }^{52}$ Conducting a collective redress procedure is very costly, in the event of failure in the dispute, enormous costs often have to be compensated for to the other party. For this purpose, both the Recommendation and the proposal for a Directive take into account the need to prove a sufficient amount of funds. This may discourage consumer organisations from dispute resolution. The proposal for a Directive is aware of this drawback and with this purpose it pays attention to the so-called assistance for qualified representative entities. Member States shall be encouraged to ensure that qualified representative entities have sufficient funds available for representative actions. They shall take the necessary measures to facilitate access to justice and shall ensure that procedural costs related to representative actions do not

51 The bill for the Collective Redress Act envisages that if the action is directed to impose an obligation to act, the plaintiff's remuneration may be up to $25 \%$ of the adjudged performance (cf. Section $\$ 101$ et seq. of the bill for the Collective Redress Act). The right of the members of the group to the adjudged performance shall be reduced accordingly. The percentage of remuneration shall be determined by the court in a resolution on the admissibility of a collective redress action (Section $\$ 44$ ). Both the Recommendation and the proposal for a Directive to emphasize the need of full compensation of damage to consumers (cf. Articles 29, 30 and 32 of the Recommendation and Article 15a of the proposal for a Directive and Article 6, Subsection 4a of the proposal for a Directive and recital 39a of the proposal for a Directive). This must be taken into account both for the fees for legal representation (the prohibition of contingency fees), the fees for the financing of third parties and the fees for the plaintiff. The bill for the Collective Redress Act therefore diverges from a European perspective on this point. Personally, however, I believe that only this step is able to ensure in the proposed Czech legislation that collective actions are brought. With regard to the topic of the paper, however, no further attention will be paid to this issue.

52 Cf. SIMON, Rita, MÜlLEROVÁ, Hana. In SIMON, Rita, MÜLLEROVÁ, Hana (eds.). Efficient Collective Redress Mechanisms in Visegrad 4 Countries: An Achievable Target? Prague: Institute of State and Law of the Czech Academy of Sciences, 2019, p. 246 et seq. 
constitute financial obstacles for qualified entities to effectively exercise the right to seek the measures referred to in Articles 5 and 6, such as limiting applicable court or administrative fees or granting them access to legal aid where necessary, or by providing them with public funding for this purpose (Article 15 of the proposal for a Directive).$^{53}$ However, this may not be sufficient, some states are actually not able to secure it. There is a risk that collective actions will not be practically used. The extension of the scope of possible plaintiffs itself (both to ad hoc entities and group members, as well as to predetermined representative entities) is, from my point view, appropriate.

At the same time, however, it is necessary to insist that the requirements for them are able to prevent abuse of this type of dispute, ensure the proper conduct of the procedure and that any unsuccessful plaintiff is able to compensate the other party's costs. This is performed by demonstrating sufficient financial resources and transparency of funds. Even the proposal for a Directive itself, which defines the range of predetermined entities relatively narrowly, requires the qualified representative entity to disclose their financial resources. This is even more necessary if we expand the range of entities entitled to legal standing.

The bill for the Collective Redress Act after comments and amendment proposals focused much more closely on the issue of financing of a procedure and its transparency than the previous bill. The conditions of demonstrating solvency is envisaged already at the stage of the certification of the procedure (in relation to this cf. also Article 14 of the Recommendation and Article 7, Subsection 1 of the proposal for a Directive). However, it must be mentioned here that the method to fulfil this requirement chosen by the bill is not able to ensure the proper conduct of the procedure and thus does not protect the members of the group itself. The deposit of the security, proof of insurance and proof of ensuring fulfilment by a bank guarantee is only able to protect the defendant, in the case of success in the dispute and reimbursement of costs by the plaintiff, however, it is not ensured that the group administrator has sufficient financial resources to properly conduct the procedure. In this respect, therefore, the bill for the Collective Redress Act diverges from the European perspective on collective protection of consumer rights. Moreover, it concerns only the opt-out procedure, in which the applicant seeks the imposition of an obligation to act. In the opt-in and optout procedure other than the one imposing the obligation act, it is possible to subordinate the issue of proper financing under section ( $\$$ ) 32, Paragraph e) of the bill for the Collective Redress Act and Paragraph g) of this Act. However,

53 However, the issue of court fees is of rather minor importance in collective redress actions. In the Czech Republic, the institute of exemption from court fees may be used. Moreover, these will have to be set up reasonably so that they neither lead to abuse, nor to discouragement, which should be valid for the provision of legal aid in general as well. However, the financing of the procedure itself and the possible reimbursement of the costs are the main issue. Cf. Article 15, Subsection 1 of the proposal for a Directive as amended after first reading. 
the plaintiff is not obliged to prove that these conditions have been fulfilled and the court takes account of the sufficient or proper funding only if it becomes apparent in the procedure. The condition of transparency of financing of the procedure is again enshrined only for the opt-out procedure (cf. Article 14 of the Recommendation and Article 7, Subsection 1 of the proposal for a Directive).

Thus, the emphasis placed by the bill for the Collective Redress Act on proper funding in the opt-out procedure seems to be a certain defence of this system, which was emphasized by the Ministry of Justice from the outset and criticized by a part of the professional public..$^{54}$

\section{Conclusion}

Limiting the legal standing to predetermined entities whose purpose is to protect the interests which are the subject of the group redress procedure is often insufficient. This is particularly the case where the horizontal concept of actions for collective redress is applied. There is simply no need for a representative to bring an action if we insist on the interconnection of the subject matter of the procedure and the purpose of the given entity, as well as its non-profit nature. Likewise, extending this scope to public authorities may not be sufficient. It may be assumed that the willingness to bring actions will be inferior here, even with regard to the range of matters falling within their jurisdiction, while they will not be equipped with sufficient machinery or time to file an action. The extension of the scope of the possible qualified representative entities approved in advance and eventually the possibility of bringing an action by ad hoc entities approved by the court ${ }^{55}$ or group members in certain procedures is therefore possible and appropriate.

Even though the entity which is the group administrator is not traditional with respect to civil procedure, its incorporation into the legislation is actually logical. It is a certain solution, which is on the borderline between a wide legal standing, where there is a risk of possible abuse of group actions and a restriction on interest groups only, which could lead to the institute not being used. However, it should be borne in mind that the requirements related to the plaintiff shall be set up in such a manner that sufficient protection for the members of the group (most often the consumers) is ensured, they would serve as a safeguard

54 The bill for the Collective Redress Act after comments and amendment proposals significantly limits the applicability of the opt-out system. Regarding the opt-out system, cf. in more detail article HAMULÁKOVÁ, Klára. Opt-Out Systems in Collective Redress EU Perspectives and Present Situation in the Czech Republic. Hungarian Journal of Legal Studies 59, No 1, pp. 95-117 (2018) DOI: 10.1556/2052.2018.59.1.6 and the literature contained therein.

55 The fact that this is necessary is also highlighted by the draft of principles of the collective redress procedure prepared by the European Law Institute (ELI) and the International Institute for Unification of Private Law (UNIDROIT) Cf. Commentary on Rule X2. 
against misuse of collective actions, but at the same time they would not de facto obstruct access to the court.

The bill for the Collective Redress Act after comments and amendment proposals is much more successful in this respect, particularly as it regards the issue of financing the procedure and its transparency. Nevertheless, it is not ideal, and I highlighted the most important shortcomings in the article.

\section{References}

Bill for the Collective Redress Act (Czech)

CCBE position on the Proposal for a Directive on representative actions for the protection of the collective interests of consumers. https://www.ccbe.eu/fileadmin/speciality_distribution/public/documents/ACCESS_TO_JUSTICE/ATJ_Position_papers/ EN_ATJ_20180924_CCBE-position-on-the-Proposal-for-a-Directive-on-representative-actions-for-the-protection-of-the-collective-interests-of-consumers-andrepealing-Directive-200922EC.pdf

Civil Code (act no. 89/2012 Coll.;Czech)

Civil Procedure Code (act no. 99/1963 Coll.;Czech)

Consumer Protection Act (act no. 634/1992 Coll.;Czech)Commission Recommendation of 11 June 2013 on common principles for injunctive and compensatory collective redress mechanisms in the Member States concerning violations of rights granted under Union law (2013/396/EU)

Directive 2009/22/EC of the European Parliament and of the Council of 23 April 2009 on injunctions for the protection of consumers' interests.

Draft of principles of the collective redress procedure prepared by the European Law Institute (ELI) and the International Institute for Unification of Private Law (UNIDROIT).

ELIÁŠ, Karel. Zpráva o VII. zasedání Kolegia pro občanské právo při Ústavu státu a práva AV ČR, v. v. i., k problematice hromadných žalob. Právník, č. 6, 2019, p. 613-616.

ELISCHER, David. Hromadné žaloby mezi Českem a Evropou. Právní rádce [online]. ISSN 1213-7693. https://pravniradce.ihned.cz/c1-66563880-hromadne-zaloby-meziceskem-a-evropou

FALLA Elodie. Powers of the judge in collective redress proceedings. Research paper submitted to BEUC, 2012, $341 \mathrm{p}$.

HAMULÁKOVÁ, Klára. Funding of Collective Actions. International and Comparative Law Review, 2016, vol. 16, no. 2, pp. 127-144. DOI: 10.1515/iclr-2016-0019.

HAMULÁKOVÁ, Klára. Opt-Out Systems in Collective Redress EU Perspectives and Present Situation in the Czech Republic. Hungarian Journal of Legal Studies 59, No 1, pp. 95-117 (2018) DOI: 10.1556/2052.2018.59.1.6.

HAMULÁKOVÁ, Klára, PETROV KŘIVÁČKOVÁ, Jana. Alternative Methods of Collective Disputes Resolution in the Czech Republic. Baltic Journal of European Studies, Tallinn University of Technology (ISSN 2228-0588), Vol. 6, No. 2 (21).

HESS, Yulia. Proposed Collective Redress in Europe in the Perspective of Deterrence of Corporate Wrongdoing. European Company Law 10, no. 3 (2013) s. 123-128.

HORA, Václav. Učebnice civilního práva procesního. Praha: Spolek čsl. právníků VŠEHRD, 1947, $602 \mathrm{p}$.

HULMÁK, Milan. Ochrana spotřebitele v rozkazním řízení. Právní rozhledy, 15-16, 2019. 
JANOUŠKOVÁ, Anežka. Návrh zákona o hromadných žalobách. Soudce, Vol. XXI., No. 1, 2019, pp. 14-22.

PARSONS, Michelle. European Class Actions. South Carolina Journal of International Law and Business, 2008, vol. 35, no. 4.

PETROV KŘIVÁČKOVÁ, Jana, HAMULÁKOVÁ, Klára. Reprezentativní žaloba v českém civilním procesu. Acta Iuridica Olomucensia, 2016, roč. 11, č. 1, pp. 51-60.

Proposal for the Directive of the European Parliament and of the Council on representative actions for the protection of the collective interests of consumers, and repealing Directive 2009/22/EC [COM/2018/184 final-2018/0089 (COD)].

Report from the Commission to the European Parliament, the Council and the European Economic and Social Committee $\operatorname{COM}(2018) 40$ final on the implementation of the Commission Recommendation of 11 June 2013 on common principles for injunctive and compensatory collective redress mechanisms in the Member States concerning violations of rights granted under Union law (2013/396/EU).

Report of the Commission on the Fitness Check of EU consumer and marketing law and a report on the implementation of the Commission Recommendation.

SIMON, Rita. Kolektivní nástroje pro řešení rozsáhlých a systémových problémů - nova forma reprezentativní žaloby? Právní rozhledy, 2019, vol. 27, no. 7, pp. 254-258.

SIMON, Rita, MÜLLEROVÁ, Hana. In SIMON, Rita, MÜLLEROVÁ, Hana (eds.). Efficient Collective Redress Mechanisms in Visegrad 4 Countries: An Achievable Target? Prague: Institute of State and Law of the Czech Academy of Sciences, 2019, 280 p.

Study Collective Redress in the Member States of the European Union prepared by Policy Deppartment for Citizens' Rights and Constitutional Affairs, October 2018, 282 p.

WINTEROVÁ, Alena. Civilní právo procesní. Díl první: řízení nalézací. Praha: Leges, 2018, 648 p. 